Gut, 1981, 22, 177-186

\title{
Human colonic intraepithelial and lamina proprial lymphocytes: cytotoxicity in vitro and the potential effects of the isolation method on their functional properties
}

\author{
M CHIBA, W BARTNIK,* S G REMINE, W R THAYER, $\dagger$ AND R G SHORTER
}

From the Mayo Clinic and Mayo Medical School, Rochester, MN, USA

SUMMARY Colonic mucosal lymphoid cells, selectively enriched for intraepithelial (IEL) or lamina proprial lymphocytes (LPL), were isolated by sequential EDTA-collagenase treatment of resected human colons. Cytotoxic activities of colonic and peripheral blood lymphoid cells (PBL) were tested in three different assays, using chicken erythrocytes (CRBC) and Chang cells as targets. Antibody-dependent cell-mediated cytotoxicity (ADCC) and PHA-induced cytotoxicity (MICC) for both targets were shown by all the isolates of PBL, as was spontaneous cell-mediated cytotoxicity (SCMC) for Chang cells. However, no SCMC or ADCC for Chang cells was found with LPL, and IEL showed minimal or no activity in either assay. PBL, LPL, and IEL demonstrated MICC for Chang cells but, contrasting with PBL and LPL, IEL showed no MICC for CRBC. No significant differences were found between the cytotoxic capabilities of colonic lymphoid cells from patients with inflammatory bowel disease and those from patients with other colonic diseases. Importantly, control studies with PBL showed that SCMC for Chang cells and ADCC for CRBC and Chang cells were reduced by the collagenase treatment used in the isolation of LPL. Also, SCMC for Chang cells was reduced by the treatment of PBL with EDTA. In contrast, neither EDTA nor collagenase reduced MICC for CRBC or Chang cells. Both forms of treatment induced variable degrees of cell losses in the PBL. By analogy, it can be implied that the isolation of intestinal mononuclear cells using EDTA and collagenase may influence some of their cytotoxic activities in vitro. This raises an important caveat in the interpretation of such studies.

Immunological mechanisms have been implicated in the pathogenesis of a number of gastrointestinal diseases, including gluten-sensitive enteropathy and non-specific inflammatory bowel disease (IBD). ${ }^{12}$ In this regard, we developed a hypothesis for the pathogenesis of IBD which included a role for cellmediated immune responses in the bowel wall. ${ }^{3}$ However, this proposal was based on observations using mononuclear cells from peripheral blood and a

\footnotetext{
*Present address: Department of Gastroenterology and Metabolism, Medical Centre of Postgraduate Education, Goszczynskiego 1, 02-616 Warsaw, Poland.

†Present address: Division of Biological and Medical Sciences, Brown University, Providence, RI 02903, USA.

¥Address for correspondence: R G Shorter, Mayo Clinic, Rochester, MN 55905, USA.

Received for publication 22 October 1980
}

question can be raised as to whether such cells reflect the functions of intestinal lymphoid tissues. ${ }^{4}$ Accordingly, firstly we isolated lamina proprial lymphoid cells from the human colon and concluded that these were capable of mediating two different antibody-dependent cell-mediated cytotoxicity assays in vitro. ${ }^{6}$

Arnaud-Battandier et $a .^{7}$ reported that intraepithelial lymphocytes from the small bowel of guinea-pigs showed cytotoxic properties different from those of lamina proprial lymphocytes. As no similar studies of the human have been described, we recently developed an EDTA-collagenase method for the selective isolation of enriched populations of colonic intraepithelial and lamina proprial lymphocytes from patients with various colonic diseases. ${ }^{8}$ The study was then extended to involve three assays of cytotoxicity for two different target cells. These 
were necessary to screen for the activity of various subsets of effector cells in the heterogeneous populations of colonic lymphoid cells. Our purpose was to seek evidence to support a role for local cellular immune responses in the pathogenesis of IBD.

\section{Methods}

\section{STUDY GROUPS}

Lymphoid cells were isolated from samples of surgically resected colons and from the peripheral blood of patients with IBD or other diseases of the large bowel. The IBD group comprised 10 patients (six women; four men), aged 16-53 years, with chronic ulcerative colitis (CUC), and 10 patients (nine women; one man), aged 16-67 years, with Crohn's disease. Eight patients (chronic ulcerative colitis, four; Crohn's disease, four) were receiving daily systemic steroids at the time of study $(20 \mathrm{mg}$ prednisone or less). Of 35 patients (16 women; 19 men), aged 44-85 years, with other colorectal diseases there were 21 with colorectal carcinoma, six with single, large colonic polyps, five with chronic diverticulitis, two with carcinoids, and one with chronic rectal prolapse. The colonic samples from the patients with IBD were taken from sites showing no ulceration and, from the patients with colonic tumours, from areas which were grossly and histologically normal. Isolates of lymphocytes were prepared from peripheral blood samples from a total of 32 healthy volunteers ( 12 women; 20 men), aged 21-54 years. The project was approved by the institutional Human Studies Committee and informed consent for blood sampling was obtained.

\section{EFFECTOR CELLS}

The methods for the isolation of colonic lymphoid cells, enriched for intraepithelial lymphocytes (IEL) or lamina proprial lymphocytes (LPL), and for the isolation of lymphoid cells from the peripheral blood (PBL) have been detailed recently. ${ }^{8}$

\section{Isolation of IEL}

Colonic mucosa, $20-40 \mathrm{~cm}^{2}$ in area, was dissected from the underlying muscularis, cut into small strips, and incubated for three minutes in calcium and magnesium-free Hank's balanced salt solution (CMF-HBSS) containing $1 \mathrm{mM}$ dithiothreitol (DTT; Grand Island Biological Co., Grand Island, NY). The mucosal pieces then were incubated with stirring at $37^{\circ} \mathrm{C}$ in air for 90 minutes in $100 \mathrm{ml}$ CMF-HBSS containing $0.7 \mathrm{mM}$ EDTA (BDH Chemicals Ltd., Poole, England), pH 7·4, to strip off epithelial cells together with the intraepithelial lymphocytes. The resulting supernatant was collected, passed through nylon mesh $(100 \mu)$, and spun in centrifuge tubes. The cell pellets then were washed twice in CMF-HBSS, pooled, and resuspended in TC 199 (Grand Island Biological Co., Grand Island, NY) containing 10\% $\mathrm{v} / \mathrm{v}$ fetal calf, serum (FCS; Grand Island Biological Co., Grand Island, NY) and antibiotics (penicillin 100 units $/ \mathrm{ml}$; streptomycin $100 \mu \mathrm{g} / \mathrm{ml}$; gentamicin $40 \mu \mathrm{g} / \mathrm{ml}$; amphotericin B $50 \mu \mathrm{g} / \mathrm{ml})$. The cell suspension then was incubated with iron filings (Lymphocyte Separator Reagent, Technicon Instruments Corp., Tarrytown, NY) for 45 minutes at $37^{\circ} \mathrm{C}$, followed by removal of the iron-containing macrophages using bar magnets. ${ }^{8}$ The cells then were washed twice, counted, and resuspended in various concentrations in TC 199 containing $10 \% \mathrm{v} / \mathrm{v}$ FCS and antibiotics (TC-FC-A), as described above. This technique gave mononuclear cell yields of 2.4 $7.5 \times 10^{6}\left(\right.$ mean $\left.\pm \mathrm{SEM}=5.6 \pm 0.5 \times 10^{6}\right)$ per $20 \mathrm{~cm}^{2}$ mucosa, with $77-94 \%$ viability (mean $=88 \pm 9 \%$ ) as estimated by trypan blue exclusion $(0 \cdot 1 \%)$. For differential counting, smears of the isolates were prepared by cytocentrifugation and stained with Wright's stain and for non-specific esterase. ${ }^{9}$ The final IEL-enriched isolates contained $94 \pm 2.7 \%$ lymphocytes, $4 \pm 2.7 \%$ eosinophils, and less than $1 \%$ of neutrophils, mast cells, and macrophages.

\section{Isolation of $L P L$}

The colonic mucosal strips, used initially to obtain IEL, were further incubated at $37^{\circ} \mathrm{C}$ in room air for 90 minutes in $100 \mathrm{ml}$ of fresh CMF-HBSS containing $0.7 \mathrm{mM}$ EDTA, pH $7 \cdot 4$. This step was repeated three to four times, each for a 90 minute period. The pieces of mucosa then were washed in CMF-HBSS and incubated with stirring for 12 hours at $37^{\circ} \mathrm{C}$ in room air in $100 \mathrm{ml}$ TC-FC-A and 3000 units of purified collagenase, type VI (Sigma Chemical Co., St. Louis, MO), with the $\mathrm{pH}$ adjusted to 7.4. After this, the supernatant was passed through nylon mesh $(100 \mu)$ and spun in centrifuge tubes. The resulting cell pellets were washed twice, pooled, and resuspended in TC-FC-A. The cell suspension was then depleted of macrophages using the method described above. This technique gave mononuclear cell yields of $2-10 \times 10^{7}$ (mean $\left.=3.8 \pm 1.6 \times 10^{7}\right)$ per $20 \mathrm{~cm}^{2}$ mucosa with $88-96 \%$ viability (mean= $92 \pm 1 \%$ as estimated using light microscopy and trypan blue exclusion $(0 \cdot 1 \%)$. Differential counts of smears prepared by cytocentrifugation and stained with Wright's stain or for non-specific esterase ${ }^{9}$ showed that the final isolates of LPL contained $91 \pm 0.5 \%$ lymphocytes, $7 \pm 2.1 \%$ plasma cells, and less than $1 \%$ macrophages, neutrophils, eosinophils, basophils, and mast cells.

The duration of the two-staged procedure for the isolation of colonic lymphoid cells was approximately 24 hours. 
Isolation of $P B L$

PBL were isolated from heparinised venous blood samples using a Ficoll-Hypaque gradient (Lymphoprep, Nyegaard \& Co., Oslo, Norway), as described by Bøyum. ${ }^{10}$ Macrophage depletion was achieved and evaluated as described above. The yields of lymphoid cells were $4-10 \times 10^{6} / 10 \mathrm{ml}$ of blood and the viabilities exceeded $95 \%$ (trypan blue $0.1 \%$ ). Differential counts of cytocentrifuge smears stained with Wright's stain or for non-specific esterase consistently showed more than $99 \%$ lymphocytes and less than $1 \%$ macrophages in the final isolates.

To evaluate the potential effects of the chemical and enzymatic treatments on the gut-derived lymphoid cells, aliquots of macrophage-depleted PBL from 10 healthy subjects were incubated in vitro with EDTA for 90 minutes or with collagenase for 12 hours, as described above for the isolation of IEL and LPL. After washing, each aliquot of PBL was counted and resuspended in various concentrations in TC-FC-A. The viabilities were estimated using trypan blue exclusion $(0 \cdot 1 \%)$.

\section{CHARACTERISATION OF T AND B \\ LYMPHOCYTES}

The macrophage-depleted isolates of PBL, LPL, and IEL were characterised for T and B cell markers as described previously. ${ }^{8}$ Immunofluorescent staining for membrane immunoglobulin was performed after the cell suspensions were incubated for 45 minutes and subsequently washed in TC 199 at $37^{\circ} \mathrm{C}$ to remove cytophilic antibody. ${ }^{11}$

\section{CYTOTOXICITY ASSAYS}

Macrophage-depleted PBL, either freshly isolated or treated with EDTA or collagenase, and the macrophage-depleted colonic isolates enriched for IEL or LPL were tested in different cytoxicity assays using two different target cells-namely, chicken erythrocytes (CRBC) and Chang cells.

Cytotoxicity assays with $C R B C$

(1) Antibody-dependent cell-mediated cytotoxicity (ADCC)

The method used essentially was that described by Perlmann and Perlmann ${ }^{12}$ Briefly, $0.25 \mathrm{ml}$ of each of the following was added to tissue culture tubes (no. 2058; Falcon, Oxnard, CA): (1) effector cells $\left(5 \times 10^{6}\right.$ viable cells/ml), (2) CRBC, labelled with $\mathrm{Na}_{2} \mathrm{CrO}_{4}$ (Sp. Act. $50-400 \mathrm{mCi} / \mathrm{mg} \mathrm{Cr}$; Amersham Corp., Arlington Heights, IL) by a method described previously, ${ }^{6}$ in a concentration of $2 \times 10^{5} \mathrm{cells} / \mathrm{ml}$, (3) heat-inactivated rabbit anti-CRBC serum (Cappel Laboratories, Cochranville, PA) diluted $10^{-6}$, an optimal dilution obtained from preliminary experiments with PBL from healthy volunteers. The viable effector to target ratio used was 25 to 1 , a ratio which had been shown by preliminary experiments with PBL to be appropriate for screening for ADCC in this assay; this ratio also permitted conservation of cells for the other testing. Controls were: (1) tubes containing ${ }^{51} \mathrm{Cr}$-labelled $\mathrm{CRBC}$ and non-labelled CRBC, (2) ${ }^{51} \mathrm{Cr}$-labelled CRBC with CRBC-antiserum and non-labelled CRBC, (3) ${ }^{51} \mathrm{Cr}$-labelled CRBC with normal rabbit serum and non-labelled CRBC, (4) tubes containing ${ }^{51} \mathrm{Cr}-\mathrm{CRBC}$ and effector cells with heat-inactivated normal rabbit serum (titre $10^{-6}$ ).

All testing was performed in duplicate. After 18 hours' incubation at $37^{\circ} \mathrm{C}$ in a humidified atmosphere containing $5 \% \mathrm{CO}_{2}$, the tubes were centrifuged, $0.5 \mathrm{ml}$ of the supernatant was removed from each tube, and the radioactivities in the supernatant $(0.5 \mathrm{ml})$ and in the pellet $(0.25 \mathrm{ml})$ were counted in a well-type gamma scintillation counter. The cytotoxicity was derived from the percentage of ${ }^{51} \mathrm{Cr}$ released and was calculated by the following formula: $\%$ cytotoxicity $=(a \times 1 \cdot 5 / a+b) \times 100$, where $a=\mathrm{cpm}$ in supernatant and $b=\mathrm{cpm}$ in pellet. Corrections were made for the spontaneous release of ${ }^{51} \mathrm{Cr}$ by the $\mathrm{CRBC}$, and cytotoxicity was expressed as the mean of duplicate tests.

\section{(2) Mitogen-induced cell-mediated cytotoxicity (MICC)}

$0.25 \mathrm{ml}$ of each of the following was added to tissue culture tubes: (1) effector cells $\left(5 \times 10^{6}\right.$ viable cells/ $\mathrm{ml}),(2){ }^{51} \mathrm{Cr}$-labelled CRBC $\left(2 \times 10^{5} / \mathrm{ml}\right)$, (3) purified PHA (Wellcome Reagents Ltd., Beckenham, England) in a final concentration of $1 \mu \mathrm{g} / \mathrm{ml}$, which, using tritium-labelled thymidine incorporation as the measure of response, was shown in six preliminary experiments to induce blastoid transformation (approximately 6,000-10,000 cpm after four days in vitro) in PBL from healthy volunteers and in colonic lymphoid isolates from IBD or cancer patients. The effector to target ratio was kept constant at 25 to 1 , and was appropriate for screening for MICC. ${ }^{13}$ Controls were: (1) tubes containing ${ }^{51} \mathrm{Cr}$-labelled CRBC, PHA, and non-labelled CRBC, (2) ${ }^{51} \mathrm{Cr}$ labelled CRBC and non-labelled CRBC, (3) tubes containing ${ }^{51} \mathrm{Cr}-\mathrm{CRBC}$ and effector cells, but no PHA. All testing was done in duplicate. The methods of incubation, final processing, calculation and expression of cytotoxicity were those described above for ADCC.

\section{Cytotoxicity assays using Chang cells as targets} (1) $A D C C$

The technique was modified from that described by MacLennan et al. ${ }^{14}$ Briefly, Chang cells (American 
Type Culture Collection, Rockville, MD)* were harvested after six minutes' incubation of monolayers in a solution containing $0.25 \%$ trypsin (Nutritional Biochemical Corp., Cleveland, $\mathrm{OH}$ ) and $0.1 \%$ EDTA in CMF-HBSS (pH 7.4). The resulting suspension was washed twice and then kept at $37^{\circ} \mathrm{C}$ for two hours in TC 199 containing $10 \% \mathrm{v} / \mathrm{v}$ FCS. Then the Chang cells were labelled with $\mathrm{Na}_{2}{ }^{51} \mathrm{CrO}_{4}$ for one hour at $37^{\circ} \mathrm{C}$, washed three times, and resuspended in a concentration of $1 \times 10^{4}$ cells $/ \mathrm{ml}$ TC-FC-A. $0 \cdot 1 \mathrm{ml}$ of each of the following was added to the wells of flat bottom type microtitre plates (Titerek; Flow Laboratories Inc., Hamden, CT): (1) ${ }^{51} \mathrm{Cr}$-labelled Chang cells $\left(1 \times 10^{4} / \mathrm{ml}\right)$, (2) effector cells in different concentrations appropriate to achieve final viable effector to target ratios of $1: 1$, $5: 1,10: 1,25: 1,50: 1,100: 1$, and (3) heat-inactivated rabbit anti-Chang serum* in a dilution of $10^{-4}$, an optimal dilution which had been determined by preliminary experiments with PBL from healthy human volunteers. Controls included: (1) ${ }^{51} \mathrm{Cr}$-labelled Chang cells incubated with antiserum, but without effector cells, (2) ${ }^{51} \mathrm{Cr}$-Chang cells, effector cells, and heat-inactivated normal rabbit serum (titre $10^{-4}$ ), (3) ${ }^{51} \mathrm{Cr}$-Chang cells in TC-FC-A for evaluation of spontaneous release of ${ }^{51} \mathrm{Cr}$.

All testing was performed in triplicate. After 18 hours' incubation at $37^{\circ} \mathrm{C}$ in a humidified atmosphere containing $5 \% \mathrm{CO}_{2}$, the microtitre plates were centrifuged $(800 \mathrm{~g})$ and $0.1 \mathrm{ml}$ aliquots of the supernatants were placed in separate counting tubes. Cytotoxicity was calculated using the following formula:

$\%$ cytotoxicity $=$

$\frac{\text { experimental } \mathrm{cpm} \text {-spontaneous release } \mathrm{cpm}}{\text { total } \mathrm{cpm} \text {-spontaneous release } \mathrm{cmp}} \times 100$,

where total $\mathrm{cpm}=$ mean $\mathrm{cpm}$ obtained from counts of six $0 \cdot 1 \mathrm{ml}$ aliquots of the radiolabelled target cell suspension. The cytotoxicity was expressed as the mean of triplicate tests.

\section{(2) $\mathrm{MICC}$}

$0.1 \mathrm{ml}$ of each of the following was added to wells of microtitre plates: (1) ${ }^{51} \mathrm{Cr}$-labelled Chang cells $\left(1 \times 10^{4} / \mathrm{ml}\right),(2)$ effector cells $\left(2.5 \times 10^{5} / \mathrm{ml}\right)$, (3) PHA in a concentration of $1 \mu \mathrm{g} / \mathrm{ml}$. The viable effector to target ratio was 25 to 1 , which, in preliminary experiments with PBL, was found to be adequate for screening for such activity, in agreement with others. ${ }^{13}$ Controls included: (1) ${ }^{51} \mathrm{Cr}$-Chang cells with PHA, but without effector cells, (2) ${ }^{51} \mathrm{Cr}$-Chang cells with effector cells, but without PHA, (3) ${ }^{51} \mathrm{Cr}$-Chang

*Kindly supplied by Drs D L Nelson and W Strober, Metabolism Branch, National Cancer Institute, Bethesda, MD, USA. cells in TC-FC-A for evaluation of spontaneous release of ${ }^{51} \mathrm{Cr}$. All testing was performed in triplicate. The methods of incubation, final processing, and calculation of cytotoxicity were those described above for ADCC for Chang cells.

(3) Spontaneous cell-mediated cytotoxicity (SCMC) $0 \cdot 1 \mathrm{ml}$ of ${ }^{51} \mathrm{Cr}$-Chang cells $\left(1 \times 10^{4} / \mathrm{ml}\right)$ was incubated in microtitre wells with $0.1 \mathrm{ml}$ of effector cells in different concentrations appropriate to achieve final viable effector to target ratios of $1: 1,5: 1,10: 1,25: 1$, $50: 1$, and 100:1. For spontaneous release of ${ }^{51} \mathrm{Cr}$, labelled Chang cells were incubated alone in TCFC-A. All testing was done in triplicate. The methods of incubation, processing, calculation, and expression of cytotoxicity were those described for ADCC for Chang cells.

\section{STATISTICAL ANALYSIS}

The results of all experiments were expressed as the mean \pm one standard error of the mean (SEM). Analysis for the significance of difference between means was done using Student's $t$ testing. A P value of 0.02 or less was demanded for significance. As no apparent differences were found between those with CUC or CD, the IBD results were considered together.

\section{Results}

MEMBRANE CHARACTERISTICS OF

LYMPHOID CELL POPULATIONS

The numbers of $T$ cells, B cells, and cells lacking these membrane characteristics (null cells) are shown in Table 1. In comparison with the peripheral blood, IEL and LPL populations each contained less $T$ cells and more $B$ cells and these differences were significant $(P<0.001)$. Also, differences were found when the two colonic lymphoid cell fractions were compared: the percentage of $\mathrm{T}$ cells in the IEL was

Table 1 Membrane characteristics of macrophagedepleted colonic mucosal and peripheral blood lymphoid cells

\begin{tabular}{llll}
\hline Source of cells & (no.) & \multicolumn{2}{c}{ Mean $\pm S E M \%$} \\
\cline { 2 - 4 } & & B & Null
\end{tabular}

PBL

$\begin{array}{lllll}\begin{array}{l}\text { PBL } \\ \text { Healthy }\end{array} & & & & \\ \text { controls } & 10 & 66 \pm 2 \cdot 7 & 13 \pm 1 \cdot 2 & \mathbf{2 1} \pm \mathbf{2 \cdot 3} \\ \text { Patients } & 26 * & \mathbf{6 2} \pm 1 \cdot 7 & 14 \pm 1 & \mathbf{2 4} \pm \mathbf{1} \cdot \mathbf{8} \\ \text { IEL } & 30 \dagger & \mathbf{3 2} \pm \mathbf{2} & \mathbf{3 4} \pm 2 \cdot 4 & \mathbf{3 4} \pm \mathbf{2} \\ \text { LPL } & 44 \ddagger & 52 \pm 1 \cdot 3 & 22 \pm 1 \cdot 1 & 26 \pm 1 \cdot 1\end{array}$

No.: number of individuals studied. inflammatory bowel disease, 12 other colonic diseases, 14. +Inflammatory bowel disease, 10; other colonic diseases, 20 . ¥Inflammatory bowel disease, 12; other colonic diseases, 32. 
lower $(P<0.001)$ than in the LPL. The content of null cells, calculated as $[100-(\mathrm{T}+\mathrm{B})] \%$, was similar in the IEL, LPL, and PBL. None of the various values apparently was influenced by disease. Other qualities of these isolates have been detailed recently elsewhere ${ }^{8}$ which support that we were testing isolates enriched for IEL and LPL respectively.

EFFECTS OF TREATMENT WITH EDTA OR COLLAGENASE ON CYTOTOXICITIES OF PBL Ninety minutes' treatment with EDTA of aliquots of macrophage-depleted PBL from 10 healthy subjects resulted in variable cell losses of 5-20\% but did not modify their MICC for CRBC or Chang cells, all relative changes being less than or equal to $\pm 2 \%$ of the cytotoxicity values shown by freshly isolated, untreated aliquots. The viabilities of the mononuclear cells exceeded $90 \%$ (trypan blue) after the EDTA treatment.

However, similar EDTA treatment of other aliquots increased their ADCC for CRBC and for Chang cells, the relative changes being $+16 \pm 3 \%$ (SEM) and $+18 \pm 4 \%$, from the respective values with untreated aliquots. Lastly, EDTA-treated PBL showed decreased SCMC for Chang cells, the mean relative change being $-28 \pm 2 \%$ of the $\%$ cytotoxicities obtained with the untreated aliquots.

Twelve hours' collagenase treatment of aliquots of the PBL resulted in viabilities in excess of $90 \%$ with variable cell losses of $6-18 \%$, and decreased ADCC for CRBC and for Chang cells. The relative changes were $-52 \pm 6 \%$ and $-30 \pm 5 \%$ of the repective cytotoxicity values with untreated aliquots. Collagenase treatment also led to a mean relative decrease of $-59 \pm 8 \%$ in the SCMC of PBL for Chang cells in respect to the values with fresh aliquots. In contrast, the same treatment of PBL led to a mean relative increase of $+20 \pm 4 \%$ in their MICC for Chang cells. However, collagenase treatment did not modify the MICC of PBL for CRBC, the relative change being only $\pm 3 \%$.

\section{ADCC FOR CRBC}

The mean value for the spontaneous release of ${ }^{51} \mathrm{Cr}$ from CRBC was $3 \cdot 7 \pm 0.7 \%$, which was not exceeded when target cells were incubated either with anti-
Table 2 Antibody dependent cell-mediated cytotoxicity for chicken erythrocytes at an effector to target ratio of $25: 1$.

\begin{tabular}{lrl}
\hline Source of effector cells & No. & $\%$ cytotoxity $($ mean $\pm S E M)$ \\
\hline$P B L$ & & \\
Healthy controls & 25 & $59 \cdot 2 \pm 3 \cdot 7$ \\
IBD & 8 & $51 \cdot 9 \pm 5 \cdot 5$ \\
Other diseases & 6 & $71 \cdot 9 \pm 8 \cdot 1$ \\
$\quad$ Total & 39 & $59 \cdot 7 \pm 3 \cdot 0$ \\
LPL & & \\
$\quad$ IBD & 18 & $39 \cdot 0 \pm 4 \cdot 1$ \\
Other diseases & 17 & $32 \cdot 4 \pm 3 \cdot 7$ \\
$\quad$ Total & 35 & $35 \cdot 8 \pm 2 \cdot 8$ \\
IEL & 6 & $4 \cdot 9 \pm 1 \cdot 7$ \\
$\quad$ IBD & 8 & $2 \cdot 1 \pm 1 \cdot 6$ \\
Other diseases & 14 & $3 \cdot 3 \pm 1 \cdot 2$ \\
$\quad$ Total &
\end{tabular}

No.: number of individuals tested. PBL: peripheral blood lymphocytes; LPL: enriched isolates of colonic lamina proprial lymphocytes; IEL: isolates enriched for colonic intraepithelial lymphocytes. All isolates were macrophage-depleted.

CRBC serum alone or with effector cells but without the specific antiserum.

The results are summarised in Table 2. All the PBL tested showed ADCC for CRBC at the screening $E: T$ of $25: 1$ and there was no significant difference between the mean value for cytotoxicity shown by the PBL from 25 healthy subjects and that with PBL from a total of 14 patients. Also, all the LPL isolates, either from patients with IBD or from those with other colonic diseases, demonstrated ADCC for CRBC, an activity which, as emphasised above, may have been diminished by the isolation procedure. In contrast, the activity of IEL was unimpressive, even though the method of isolation potentially might have increased their activity. Six of the total of 14 samples of IEL showed zero activity, and in the remaining eight the cytotoxicities were modest, only one achieving approximately $10 \%$. In addition, the finding of no apparent relationship between the ADCC for CRBC shown by IEL and LPL isolated from the same colonic mucosa suggested that these were functionally distinct populations of cells (Table 3 ).

ADCC AND SCMC FOR CHANG CELLS

The mean spontaneous release of ${ }^{51} \mathrm{Cr}$ from Chang cells was $18 \cdot 1 \pm 1 \cdot 7 \%$ which was not exceeded with

Table 3 Comparison between ADCC activities in CRBC system shown by representative IEL and LPL populations isolated from same colons (effector to target ratio, 25:1)

\begin{tabular}{|c|c|c|c|c|c|c|c|c|c|c|c|c|}
\hline \multirow[t]{2}{*}{ Source of cells } & \multicolumn{8}{|c|}{$\%$ specific cytotoxicity } & & & & \multirow[b]{2}{*}{$\begin{array}{l}\text { Total cases } \\
\text { Mean } \pm S E M\end{array}$} \\
\hline & \multicolumn{3}{|c|}{$\begin{array}{l}\text { Colorectal cancer } \\
(5 \text { cases })\end{array}$} & \multicolumn{5}{|c|}{$\begin{array}{l}\text { IBD } \\
\text { (6 cases) }\end{array}$} & & & & \\
\hline $\begin{array}{l}\text { IEL } \\
\text { LPL }\end{array}$ & $\begin{array}{l}12 \cdot 7 \\
58 \cdot 8\end{array}$ & $\begin{array}{r}2 \cdot 7 \\
33 \cdot 6\end{array}$ & $\begin{array}{c}0 \\
48 \cdot 2\end{array}$ & $\begin{array}{c}0 \\
39 \cdot 9\end{array}$ & $\begin{array}{c}0 \\
20 \cdot 7\end{array}$ & $\begin{array}{l}10 \cdot 8 \\
24 \cdot 8\end{array}$ & $\begin{array}{r}7 \cdot 6 \\
50.6\end{array}$ & $\begin{array}{r}6 \cdot 6 \\
61 \cdot 6\end{array}$ & $\begin{array}{r}3 \cdot 4 \\
32 \cdot 3\end{array}$ & $\begin{array}{r}1 \cdot 2 \\
21 \cdot 8\end{array}$ & $\begin{array}{c}0 \\
25 \cdot 5\end{array}$ & $\begin{array}{r}4 \cdot 1 \pm 1 \cdot 4 \\
38 \pm 4 \cdot 5\end{array}$ \\
\hline
\end{tabular}




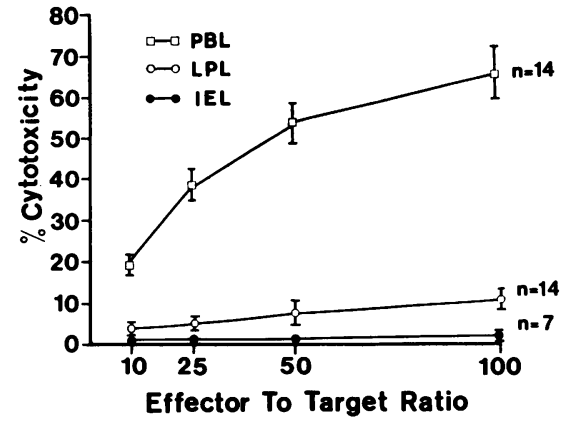

Fig 1 ADCC for Chang cells shown by PBL, LPL, and IEL at different effector to target ratios. All values represent the mean \pm 1 SEM. The values for LPL are uncorrected for SCMC (see text).

the addition of anti-Chang serum or normal rabbit serum.

Figs. 1 and 2 show the results in the Chang cell ADCC and SCMC assays. In Fig. 1 the ADCC values are not corrected for SCMC. The two tests were performed simultaneously using: (1) PBL isolates from five healthy subjects and nine patients, (2) LPL isolates from four patients with IBD and 10 with other colonic diseases, and (3) IEL isolates from four patients with IBD and three others. No ADCC or SCMC was observed using PBL, LPL, or IEL at effector: target ratios (E:T) of $1: 1$ and $5: 1$, so these are excluded from the graphs. At higher ratios, all the PBL isolates showed ADCC for Chang cells, with a mean cytoxicity value of $65 \cdot 1 \pm 6 \%$ at $\mathrm{E}: \mathrm{T}$ of 100:1 (Fig. 1). On testing the colonic lymphoid cell isolates, LPL appeared to be modestly active in mediating ADCC with a mean value of $10 \cdot 4 \pm 2 \cdot 8 \%$, but the IEL were inactive.

In the SCMC assay, PBL from healthy controls

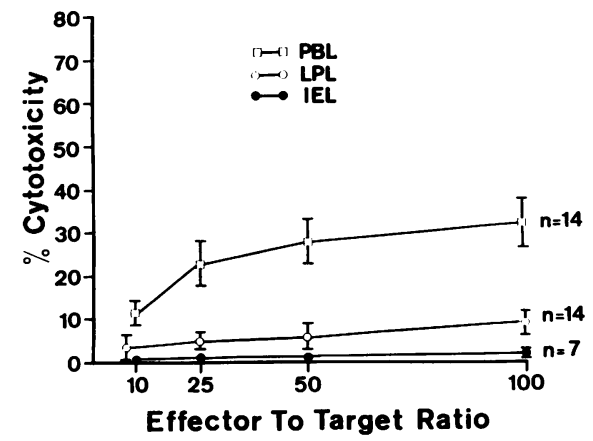

Fig. 2 SCMC for Chang cells shown by PBL, LPL, and IEL at different effector to target ratios. All values represent the mean \pm 1 SEM. and from patients, regardless of the nature of the disease, were cytotoxic for Chang cells. The mean SCMC for the 14 PBL so tested was $31 \cdot 2 \pm 5.6 \%$ at E:T of 100:1 (Fig. 2). With LPL, two patients out of the total of 14 showed no activity but in the remaining 12 the SCMC ranged from 4 to $35 \%$ at E:T of 100:1. The overall mean value for the SCMC shown by the 14 isolates of LPL tested was $8 \cdot 7 \pm 2.6 \%$, which was considered to be low but definite cytotoxicity. In contrast, all the IEL were inactive with a mean cytotoxicity value of $1 \cdot 2 \pm 0.5 \%$ at the same E:T.

However, because SCMC may have contributed to the cytotoxicity found in the Chang cell assay for ADCC, a subtraction of the \% SCMC from the ADCC obtained with the same lymphocytes permitted a simple correction. When this was done, all the PBL tested showed 'corrected' ADCC for Chang cells, with a mean value of $39.9 \pm 6.1 \%$ at $E$ :T of $100: 1$. In contrast, of the 14 samples of LPL, seven showed no 'corrected' ADCC for Chang cells at the same E:T, and for the remaining seven the mean value was only $3.4 \pm 0.9 \%$.

\section{MICC FOR CRBC AND CHANG CELLS}

The spontaneous release of ${ }^{51} \mathrm{Cr}$ from $\mathrm{CRBC}$ or Chang cells, given above, was not exceeded when target cells were incubated only in the presence of PHA.

MICC for CRBC and Chang cells shown by LPL were similar to that demonstrated by the freshly isolated PBL (Fig. 3) at the screening E:T of 25:1. While the IEL showed no MICC activity in the CRBC assay, MICC for Chang cells was demonstrable. The differences between the mean values for MICC for Chang cells shown respectively by PBL, LPL, and IEL (30.7 $\pm 6 \cdot 3 \%, 23.5 \pm 5 \cdot 1 \%$, and $11.6 \pm$ $4.4 \%$ ) were not significant. In contrast, MICC for CRBC shown by IEL was essentially zero (mean

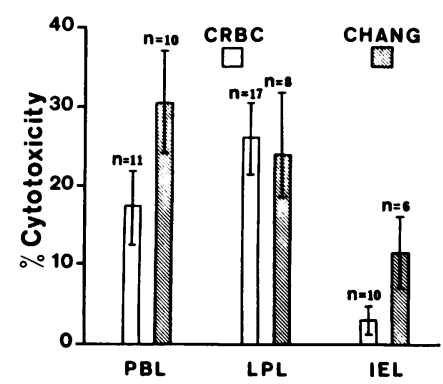

Fig. 3 PHA-induced MICC for CRBC and Chang cells shown by $P B L, L P L$, and IEL at an effector:target ratio of $25: 1$. All values represent the mean \pm 1 SEM. 
$3 \pm 1.7 \%$ ) in contrast with that found with PBL $(17.5 \pm 3.9 \%)$ or with LPL $(26.1 \pm 4 \cdot 6 \%)$ at the same E:T. These comparisons of MICC demonstrated by the different lymphoid isolates were valid, as control studies with PBL showed that neither EDTA nor collagenase treatment reduced their MICC activity.

Lastly, the mean values for ADCC, SCMC, or MICC for Chang cells did not differ depending on the nature of the colonic disease and the same was true when CRBC were used as targets for ADCC and MICC. In addition, neither ADCC, SCMC, nor MICC shown by PBL, LPL, or IEL was demonstrably influenced in the patients with IBD who were receiving steroid treatment.

\section{Discussion}

Sequential treatment of human colonic mucosa with EDTA and collagenase (EDTA-C) was used to isolate lymphoid cells enriched for intraepithelial lymphocytes (IEL) or lamina proprial lymphocytes (LPL). The IEL contained approximately equal proportions of T, B, and null cells, whereas the LPL showed a higher percentage of $T$ cells and somewhat lower proportions of $B$ and null cells, and these values did not differ with disease. Treatment with EDTA-C has been shown to have only modest effects (relative change: -7 to $+9 \%$ ) on the proportion of $T$ cells in similar characterisations of control PBL, with negligible relative change in the percentage of B cells. ${ }^{8}$ Thus, as emphasised in our previous report, ${ }^{8}$ we concluded that we were obtaining preparations selectively enriched for IEL and LPL. Our findings in LPL contrasted somewhat with those of Bull and Bookman ${ }^{5}$ who reported a lower percentage of $B$ cells and that null cells were not present, and with those of MacDermott et al. ${ }^{15}$ in their patients with IBD. Goodacre et al.,16 who used mechanical isolation, found a lower percentage of $T$ cells in human colonic LPL compared with those observed either by Bull and Bookman ${ }^{5}$ or by Bartnik et al. ${ }^{8}$ using EDTA-C isolation. However, neither Bull and Bookman ${ }^{5}$ nor Goodacre et al.$^{16}$ studied colonic IEL. Lastly, MacDermott et al. ${ }^{17}$ showed that ' $\mathrm{K}$ ' lymphocytes were present in their EDTA-C isolates of human colonic LPL and Strickland et al.$^{18}$ found null cells in tissue sections of human colonic lamina propria. Thus, the major classes of lymphocytesnamely, T, B, and null cells-are represented in EDTA-C isolates of human colonic IEL and LPL, but relatively little is known of the nature and properties of their subsets.

Several groups have found that ADCC and SCMC for various targets, including $C R B C$ and Chang cells, can be mediated by subsets of Fc receptor- bearing null cells, ${ }^{13-22}$ and also by subsets of $T$ lymphocytes, ${ }^{23-25}$ particularly those possessing receptors for IgG. ${ }^{26}$ The present results imply that such subsets were well represented in the peripheral blood, as evidenced by the high cytotoxicity values obtained with the macrophage-depleted PBL isolates in the ADCC and SCMC assays. Our finding that ADCC for CRBC and Chang cells shown by PBL did not vary with the disease agrees with the observation of Britton et al. ${ }^{27}$ using mouse lymphoma cells as targets, but contrasts with results showing that CRBC-ADCC shown by PBL from patients with active IBD was decreased ${ }^{28}$ or increased ${ }^{29}$ compared with healthy controls. The reasons for these discrepancies are not apparent. Importantly, we demonstrated that human colonic LPL, but not IEL, mediated strong ADCC for chicken erythrocytes. Because our isolates were depleted of polymorphonuclear leucocytes and macrophages, it can be inferred that ' $\mathrm{K}$ ' lymphocyte activity was present in the LPL. ${ }^{13}$ This finding of ADCC for CRBC with LPL is in agreement with our previous study ${ }^{6}$ and those of others. ${ }^{1730}$ In contrast, also using an enzymatic isolation technique, Fiocchi et al.$^{31}$ found essentially no ADCC for CRBC with human colonic LPL (Table 4).

Although colonic LPL mediated SCMC for Chang cells, IEL were inactive. However, in the ChangADCC system, while IEL were inactive, the apparent ADCC of LPL was also reduced effectively to zero when corrected for SCMC. This finding contrasts with a previous study in our laboratory in which ADCC for Chang cells was shown by some isolates of colonic LPL. ${ }^{6}$ We conclude that the discrepancies between the Chang-ADCC results in the two studies were due to technical factors, including particularly the use of different antisera, and the lower ratio of effector to target cells in the previous SCMC assays. We consider now that ADCC for Chang cells was not demonstrated by colonic LPL isolated by the EDTA$\mathrm{C}$ technique. However, in agreement with our previous findings, ${ }^{6}$ MacDermott et $a l^{30}$ also found ADCC for Chang cells with some suspensions of LPL isolated using EDTA-C, but could detect no such activity in a subsequent study. ${ }^{17}$ Furthermore, in an earlier report ${ }^{30}$ they found SCMC for Chang cells with some isolates of LPL, as in the experiments reported herein, but failed to confirm this subsequently. ${ }^{17}$ Nevertheless, we and MacDermott et al. ${ }^{17}$ now generally agree on the findings with EDTA-C isolated human colonic LPL in the CRBC and Chang cytotoxicity assays, with the exception of the conclusions from the Chang-SCMC experiments (Table 4).

Others also have tested human colonic LPL for ADCC for Chang cells, ${ }^{32}{ }^{33}$ and the somewhat con- 
troversial results are summarised in Table 4. In addition, human LPL also have shown variable SCMC and ADCC using other cell lines as targets. ${ }^{17} 303435$

In our experiments, MICC for CRBC was shown by colonic LPL but not by IEL. However, MICC for Chang cells was demonstrated by LPL and by IEL and, to our knowledge, no previous reports exist of the testing of human colonic IEL for such activity. Of importance to the interpretation of these findings, others concluded that MICC for CRBC, using PBL depleted of polymorphonuclear leucocytes and macrophages, can be mediated by subsets of $\mathrm{T}, \mathrm{B}$, or null cells, whereas MICC for Chang cells is a property of a T-cell subset. ${ }^{13}$ Lastly, human LPL also were found to mediate MICC for human erythrocytes, using colonic mononuclear cells isolated by the EDTA-C method. ${ }^{17} 30$

In this study the cytotoxic activities of IEL, and those of colonic LPL, differed from those found by Arnaud-Battandier et al. ${ }^{7}$ in guinea-pigs; they reported that small intestinal IEL, isolated mechanically, mediated ADCC, SCMC, and MICC for Chang cells, whereas LPL, isolated using collagenase, showed only MICC. The discordance between the findings in the two studies cannot be explained by limited viability of our cells but may reflect species differences and the different loci from which the cells were derived. However, it is possible that influences of the isolation procedures also may be involved, a point which will be discussed later.

It is clear that agreement and disagreement exist on the cytotoxic properties in vitro of isolates of human colonic LPL, especially in their SCMC and ADCC for cell-lines (Table 4). While these discrepancies might be explicable in part by technical variations in the cytotoxicity assays or by differences in the patients studied, the methods of isolation of colonic mononuclear cells probably influence their functional behaviour in vitro. To illustrate this, Bland et $a .^{33}$ found synthesis of $\mathrm{PGE}_{2}$ during the mechanical isolation of human colonic LPL. In discussion they emphasised that many studies ${ }^{36-43}$ have shown that $\mathrm{E}$ series prostaglandins may inhibit some functions of lymphocytes in vitro. Thus, the production of $\mathrm{PGE}_{2}$ must be recognised in the interpretation of any future experiments using their mechanical method for the isolation of LPL. An inhibitory effect of $\mathrm{PGE}_{2}$ might explain the delayed and reduced mitogenic response to PHA of human LPL in vitro, compared with PBL, which was found by Goodacre et al. ${ }^{16}$

Another variable is the possible loss of cells during isolation. To reduce such losses, Bland et al. ${ }^{33}$ stressed the merit of isokinetic gradient purification compared with discontinuous gradients. Importantly, their mechanical isolation of LPL was similar to that used by Goodacre et $a{ }^{16}{ }^{16}$ but differed from the 'rubbing' technique used by Arnaud-Battandier et al. ${ }^{7}$ In our study, EDTA or collagenase treatment of control PBL caused variable cell losses and reduced certain cytotoxic activities. Accordingly, similar effects might be exerted on colonic mononuclear cells by this isolation method, although it must be stressed that our control findings differed from those in other reports, ${ }^{61735}$ for unexplained reasons. Unfortunately, in our experiments the sizes of the colonic mucosal samples available were insufficient to permit the use of a mechanical ${ }^{16}$ and the EDTA-C techniques in parallel. Nevertheless, our observations, and those of Bland et al. ${ }^{33}$ raise the important question of whether technical artefacts, resulting from current isolation techniques, may be introduced into the subsequent testing of the

Table 4 Summary of data from various studies of in vitro cytotoxicities of human colonic lamina proprial lymphocytes (LPL) or intraepithelial lymphocytes (IEL) for Chang cells or chicken red blood cells (CRBC)

\begin{tabular}{|c|c|c|c|c|c|c|}
\hline Reference & Effector cells & Isolation method & $T C$ & $A D C C$ & $S C M C$ & $M I C C$ \\
\hline This study & $\begin{array}{l}\text { LPL } \\
\text { IEL } \\
\text { LPL } \\
\text { IEL }\end{array}$ & $\begin{array}{l}\text { EDTA-C } \\
\text { EDTA } \\
\text { EDTA-C } \\
\text { EDTA }\end{array}$ & $\begin{array}{l}\text { Chang } \\
\text { Chang } \\
\text { CRBC } \\
\text { CRBC }\end{array}$ & $\begin{array}{l}0 \\
0 \\
+ \\
0\end{array}$ & $\begin{array}{c}+ \\
0 \\
\text { nt } \\
\text { nt }\end{array}$ & $\begin{array}{l}+ \\
+ \\
+ \\
0\end{array}$ \\
\hline Fiocchi et al. ${ }^{31}$ & LPL & C-R & CRBC & \pm & nt & nt \\
\hline Chiba et al. ${ }^{6}$ & $\begin{array}{l}\text { LPL } \\
\text { LPL }\end{array}$ & $\begin{array}{l}\text { EDTA-C } \\
\text { EDTA-C }\end{array}$ & $\begin{array}{l}\text { Chang } \\
\text { CRBC }\end{array}$ & $\begin{array}{l}+ \\
+\end{array}$ & $\underset{n t}{ \pm}$ & $\begin{array}{l}\text { nt } \\
\text { nt }\end{array}$ \\
\hline MacDermott et al. ${ }^{17}$ & LPL & $\begin{array}{l}\text { EDTA-C } \\
\text { EDTA-C }\end{array}$ & $\begin{array}{l}\text { Chang } \\
\text { CRBC }\end{array}$ & $\begin{array}{l}0 \\
+\end{array}$ & \pm & $\begin{array}{l}0 \\
\text { nt }\end{array}$ \\
\hline $\begin{array}{l}\text { Clancy and Pucci }{ }^{32} \\
\text { Bland et al. } .^{33}\end{array}$ & $\begin{array}{l}\text { LPL } \\
\text { LPL } \\
\text { LPL }\end{array}$ & $\begin{array}{l}\text { M } \\
\text { EDTA-C } \\
M\end{array}$ & $\begin{array}{l}\text { Chang } \\
\text { Chang } \\
\text { Chang }\end{array}$ & $\begin{array}{l}0 \\
+ \\
0\end{array}$ & $\begin{array}{l}\text { nt } \\
? \\
?\end{array}$ & $\begin{array}{l}\text { nt } \\
\text { nt } \\
\text { nt }\end{array}$ \\
\hline
\end{tabular}

TC: target cell; EDTA-C: EDTA-collagenase; $\mathbf{M}$ : mechanical; C-R: collagenase-ribonuclease; ADCC: antibody-dependent cell-mediated cytotoxicity; SCMC: spontaneous cell-mediated cytotoxicity; MICC: mitogen-induced cytotoxicity; nt: not tested. 
cytotoxic properties of human colonic monuclear cells in vitro.

Our thanks are due to the Departments of Surgical Pathology and Surgery for their co-operation; to Mrs $\mathrm{S}$ Collyer of the Mayo Clinic for her technical help and to Mrs C Charland, Rhode Island Hospital, Providence, RI, for assistance with the illustrations. This study was supported in part by grants from the NIH, USPHS (AM 18634), and from the National Foundation for Ileitis and Colitis. Dr W Bartnik was in receipt of a Public Health Service International Fellowship (FO5 TWO 2727).

\section{References}

${ }^{1}$ Ferguson A. Celiac disease and gastrointestinal food allergy. In: Ferguson A, MacSween RNM, eds. Immunological aspects of the liver and gastrointestinal tract. Lancaster: MTP Press, 1976: 153-202.

${ }^{2}$ Jewell DP, Hodgson HJF. Autoimmune and inflammatory diseases of the gastrointestinal tract. In: Ferguson A, MacSween RNM, eds. Immunological aspects of the liver and gastrointestinal tract. Lancaster: MTP Press, 1976: 203-50.

${ }^{3}$ Shorter RG, Huizenga KA, Spencer RJ. A working hypothesis for the etiology and pathogenesis of nonspecific inflammatory bowel disease. Am J Dig Dis 1972; 17: 1024-32.

${ }^{4}$ Clancy R, Bienenstock J. Enteric infection and immunization. In: Ferguson A, MacSween RNM, eds. Immunological aspects of the liver and gastrointestinal tract. Lancaster: MTP Press, 1976: 121-52.

${ }^{5}$ Bull DM, Bookman MA. Isolation and functional characterization of human intestinal mucosal lymphoid cells. J Clin Invest 1977; 59: 966-74.

${ }^{6}$ Chiba M, Shorter RG, Thayer WR, Bartnik W, ReMine S. K-cell activity in lamina proprial lymphocytes from the human colon. Dig Dis Sci 1979; 24: 817-22.

${ }^{7}$ Arnaud-Battandier F, Bundy BM, O'Neil M, Bienenstock J, Nelson DL. Cytotoxic activities of gut mucosal lymphoid cells in guinea pigs. J Immunol 1978; 121: 1059-65.

${ }^{8}$ Bartnik W, ReMine SG, Chiba M, Thayer WR, Shorter RG. Isolation and characterization of human colonic intraepithelial and lamina proprial lymphocytes. Gastroenterology 1980; 78: 976-85.

${ }^{9} \mathrm{Li}$ CY, Lam KW, Yam LT. Esterases in human leukocytes. J Histochem Cytochem 1973; 21 : 1-12.

${ }^{10}$ Bøyum A. Separation of leukocytes from blood and bone marrow. Scand J Clin Lab Invest 1968; 21: (suppl 97): 31-50.

${ }^{11}$ Kumagai K, Abo T, Sekizawa T, Sasaki M. Studies of surface immunoglobulins on human B lymphocytes: $I$. Dissociation of cell-bound immunoglobulins with acid pH or at $37^{\circ} \mathrm{C}$. J Immunol 1975; 115: 982-7.

${ }^{12}$ Perlmann P, Perlmann H. Contactual lysis of antibodycoated chicken erythrocytes by purified lymphocytes. Cell Immunol 1970; 1 : 300-15.
${ }^{13}$ Nelson DL, Bundy BM, Pitchon HE, Blaese RM, Strober W. The effector cells in human peripheral blood mediating mitogen-induced cellular cytotoxicity and antibody-dependent cellular cytotoxicity. J Immunol 1976; 117: 1472-81.

${ }^{14}$ MacLennan ICM, Loewe C, Howard A. A human serum immunoglobulin with specificity for certain homologous target cells, which induces target cell damage by normal human lymphocytes. Immunology 1969; 17: 897-910.

${ }^{15}$ MacDermott RP, Bragdon MJ, Jenkins KM, Franklin GO, Shedlofsky S, Kodner IJ. Investigation of T cell function by isolated human intestinal mononuclear cells (abstr). Gastroenterology 1980; 78: 1213.

${ }^{16}$ Goodacre R, Davidson R, Singal D, Bienenstock J. Morphologic and functional characteristics of human intestinal lymphoid cells isolated by a mechanical method. Gastroenterology 1979; 76: 300-8.

${ }^{17}$ MacDermott RP, Franklin GO, Jenkins KM, Kodner IJ, Nash GS, Weinrieb IJ. Human intestinal mononuclear cells. I. Investigation of antibody-dependent, lectin-induced and spontaneous cell-mediated cytotoxic capabilities. Gastroenterology 1980; 78: 47-56.

${ }^{18}$ Strickland RG, Husby G, Black WL, Williams RL Jr. Peripheral blood and intestinal lymphocyte subpopulations in Crohn's disease. Gut 1975; 16: 847-53.

${ }^{19}$ Nelson DL, Bundy BM, Strober W. Spontaneous cellmediated cytotoxicity by human peripheral blood lymphocytes in vitro. J Immunol 1977; 119: 1401-05.

${ }^{20}$ Perussia B, Trinchieri G, Cerottini J-C. Functional studies of Fc receptor-bearing human lymphocytes: effect of treatment with proteolytic enzymes. $J$ Immunol 1979; 123: 681-7.

${ }^{21}$ Hersey P, Edwards A, Edwards J. Characterization of mononuclear effector cells in human blood. Clin Exp Immunol 1976; 23: 104-13.

${ }^{22}$ Perlmann P, Biberfeld P, Larsson A. Surface markers of antibody dependent lymphocytic effector cells (K-cells) in human blood. In: Seligmann M, Preudhomme JL, Kourilsky FM, eds. Membrane receptors of lymphocytes. Amsterdam-Oxford: North-Holland, 1975: 161-9.

${ }^{23}$ West WH, Cannon GB, Kay HD, Bonnard GD, Herberman RB. Natural cytotoxic reactivity of human lymphocytes against a myeloid cell line: characterization of effector cells. J Immunol 1976; 118: 355-61.

${ }^{24}$ West WH, Boozer RB, Herberman RB. Low affinity E-rosette formation by the human $\mathrm{K}$ cell. $J$ Immunol 1978; 120: 90-5.

${ }^{25}$ Caraux J, Thierry C, Serrou B. Quantitative comparison of $\mathbf{K}$ cell potential in human $\mathbf{T}$ and null cells. Eur $J$ Immunol 1978; 8: 806-12.

${ }^{26}$ Gupta S, Fernandes G, Nair M, Good RA. Spontaneous and antibody-dependent cell-mediated cytotoxicity by human $\mathrm{T}$ cell subpopulations. Proc Natl Acad Sci 1978; 75: 5137-41.

${ }^{27}$ Britton S, Eklund AE, Bird AG. Appearance of killer (K) cells in the mesenteric lymph nodes in Crohn's disease. Gastroenterology 1978; 75: 218-20.

${ }^{28}$ Dronfield MW, Langman MJS. Killer cell activity and numbers in inflammatory bowel disease (Abstract). Gut 1977; 18: 971.

${ }^{29}$ Eckhardt R, Kloos P, Dierich MP, Meyer Zum Büschenfelde KH. K-lymphocytes (killer-cells) in 
Crohn's disease and acute virus B-hepatitis. Gut 1977; 18: $1010-6$

${ }^{30}$ MacDermott RP, Jenkins KM, Franklin GO, Weinrieb IJ, Nash GS, Kodner IJ. Antibody dependent (ADCC), spontaneous (SMCC) and lectin induced (LICC) cellular cytotoxicity by human intestinal lymphocytes (Abstract). Gastroenterology 1979; 76: 1190.

${ }^{31}$ Fiocchi C, Battisto JR, Farmer RG. Gut mucosal lymphocytes in inflammatory bowel disease: isolation and preliminary functional characterization. Dig Dis Sci 1979; 24: 705-17.

${ }^{32}$ Clancy R, Pucci A. Absence of $\mathrm{K}$ cells in human gut mucosa. Gut 1978; 19: 273-6.

${ }^{33}$ Bland PW, Richens ER, Britton DC, Lloyd JV. Isolation and purification of human large bowel mucosal lymphoid cells: effect of separation technique on functional characteristics. Gut 1979; 20: 1037-46.

${ }^{34}$ Falchuk ZM, Barnhard E, Machado I. Human colonic lamina propria lymphocytes mediate mitogen-induced but not spontaneous cell mediated cytotoxicity (Abstract). Gastroenterology 1979; 76: 1129.

${ }^{35}$ Bookman MA, Bull DM. Characteristics of isolated intestinal mucosal lymphoid cells in inflammatory bowel disease. Gastroenterology 1979; 77: 503-10.

${ }^{36}$ Cook RG, Stavitsky AB, Harold WW. Regulation of the in vitro anamnestic antibody response by cyclic AMP. II. Antigen-dependent enhancement by exogenous prostaglandins of the E series. Cell Immunol 1978; 40: 128-40.
${ }^{37}$ Lomnitzer R, Rabson AR, Koornhof HJ. The effects of cyclic AMP on leucocyte inhibitory factor (LIF) production and on the inhibition of leucocyte migration. Clin Exp Immunol 1976; 24: 42-8.

${ }^{38}$ Smith JW, Steiner AL, Newburry WM Jr, Parker CW. Cyclic adenosine $3^{\prime}: 5^{\prime}$-monophosphate in human lymphocytes. Alteration after phytohemagglutinin stimulation. J Clin Invest 1971; 50: 432-41.

${ }^{39}$ Smith JW, Steiner AL, Parker CW. Human lymphocyte metabolism. Effects of cyclic and noncyclic nucleotides on stimulation by phytohemagglutinin. $J$ Clin Invest $1971 ; 50$ : 442-8.

${ }^{40}$ Goodwin JS, Bankhurst AD, Messner RP. Suppression of human T-cell mitogenesis by prostaglandin. Existence of a prostaglandin-producing suppressor cell. $J$ Exp Med 1977; 146: 1719-34.

${ }^{41}$ Goodwin JS, Messner RP, Bankhurst AD, Peake GT, Saiki JH, Williams RL Jr. Prostaglandin-producing suppressor cells in Hodgkin's disease. $N$ Engl J Med 1977; 297: 963-8.

${ }^{42}$ Droller MJ, Perlmann P, Schneider MV. Enhancement of natural and antibody-dependent lymphocyte cytotoxicity by drugs which inhibit prostaglandin production by tumor target cells. Cell Immunol 1978; 39: 154-64.

${ }^{43}$ Droller MJ, Schneider MV, Perlmann P. A possible role for prostaglandins in the inhibition of natural and antibody-dependent cell-mediated cytotoxicity against tumor cells. Cell Immunol 1978; 39: 165-77. 